\title{
Fallokracja czy waginocentryzm? Głos feministek we współczesnej debacie o płci, języku i kulturze
}

\begin{abstract}
Straszne rzeczy musiała ludzkość wyrzadzić samej sobie, by stworzyć jaźń, tożsamy, nastawiony na osiaganie celów, męski charakter człowieka $[\ldots]$.

Max Horkheimer, Theodor W. Adorno, Dialektyka Oświecenia Nie ma wypowiedzi w ogóle, wypowiedzi wolnej, neutralnej i niezależnej. Zawsze jest ona częścia jakiegoś ciagu lub zbioru, odgrywajac jakaśs role pośród innych wypowiedzi, opierajac się na nich i odróżniajac od nich.
\end{abstract}

Michel Foucault, Archeologia wiedzy

Wokół feminizmu narosło od początku mnóstwo legend, mitów i nie zawsze wiarygodnych opowieści, które wynikały w dużej mierze z niezrozumienia jego idei. Jako krytyka społeczno-politycznej opresji kobiet w społeczeństwie patriarchalnym, a także pewien styl filozoficznego myślenia w kategoriach „różnicy” i ,inności”, feminizm wielokrotnie spotykał się z przedrefleksyjnym i przedkrytycznym odrzuceniem. Do dziś jest przedstawiany karykaturalnie i stereotypowo. Sporą „zasługę" w takim podejściu do feminizmu mają media, które większość opowieści o kobiecym ruchu budują wokół „zazębiających się działań antagonisty i protagonisty"1.

Feministkom zarzuca się wiele: ideologiczność przekazu, nadwrażliwość, obrażalstwo, „pilnowanie czystości myśli i języka”, „bolszewicką pewność jedynie słusznej prawdy" itd. ${ }^{2}$ Przeciwnicy ruchu feministycznego próbują go zdyskredytować, wskazując na ogromne, ich zdaniem, podobieństwo pomiędzy argumentacją feministek i marksistów, co bywa

1 M. Mrozowski, Media masowe: władza, rozrywka i biznes, Warszawa 2001, s. 318 .

2 E. Wilk, Feministki, w: Tabu: o czym szczerze nie rozmawiamy, „Polityka” nr 25 (2406), 21 czerwca 2003, s. 85. 
traktowane jako straszak skuteczny szczególnie w krajach postkomunistycznych ${ }^{3}$. Niepokój wywołuje zwłaszcza „rewolucyjna” retoryka ruchu kobiecego: żądanie przez feministki równego statusu dla kobiet i mężczyzn brzmi niemal tak złowieszczo(?) jak postulat „równości wszystkich ludzi” głoszony przez marksistów; „,walka płci” przywodzi na myśl ,walkę klas", której zwieńczeniem - w myśl starej prawdy o odwracalności porządku społeczno-politycznego - mogą być tylko i wyłącznie dyktatorskie rządy kobiet i degradacja rodzaju męskiego.

Feministycznej krytyce patriarchalnej kultury, fallokratycznego języka i neutralnego (a w istocie męskiego) podmiotu towarzyszą oskarżenia o „kryptowaginocentryzm”4 - dążenie do zastąpienia jednego paradygmatu (znanego, oswojonego) innym (Innym, czyli obcym, niepojętym, nieznanym). W tym nowym układzie symbolicznego Fallusa miałaby zastapić Wagina, z patriarchatu wiodłaby prosta droga do matriarchatu, a fikcyjny świat „Seksmisji” stałby się rzeczywistością. Zarzuty te, wysuwane głównie przez konserwatywnych krytyków, podchwytują media i w formie żartów przekazują do wiadomości opinii publicznej. W dziennikarskich relacjach feminizm objawia się jako „choroba”, „niebezpieczna ideologia”, „dziwne zjawisko”, z którym można sobie poradzić, „ośmieszając jego język i ukazując jego próby zaistnienia w sferze publicznej jako żałosną farsę"5.

\section{1. „Dyskurs Innych”: feministki w mediach}

Maciej Mrozowski, zajmujący się kwestią masowej komunikacji, zwraca uwagę, że konstrukcja dziennikarskiej relacji jest podobna do struktury mitycznej w ujęciu Lévi-Straussa ${ }^{6}$. Sprowadza się ona do analizy zdarzeń wywołanych przez działania antagonisty, które „naruszają ustalony porządek i stwarzają zagrożenie dla systemu społecznego, świata

3 Pisze o tym m.in. A. Snitow, Przyszłość feminizmu w krajach postkomunistycznych, przeł. B. Limanowska, w: Spotkania feministyczne, pod red. B. Limanowskiej, T. Oleszczuk, Warszawa 1994/1995, s. 6-11.

4 Por. np. P. Skórzyński, Feminokracja?, „Rzeczpospolita” Plus Minus, 25.10.2003.

5 A. Graff, Feminizm na rozstajach: między polityka, kultura, a nauka, w: Socjologia przemiany współczesnego świata, pod red. I. Krzemińskiego, Warszawa 2004, s. 214.

6 C. Lévi-Strauss, Antropologia strukturalna, przeł. K. Pomian, Warszawa 1970 (rozdział XI: Struktura mitów). 
życia jakiejś zbiorowości lub dla poszczególnych jednostek"”. Zorganizowane kroki ludzi oraz instytucji występujących w interesie własnym lub społeczeństwa, będące odpowiedzią na działania antagonisty, skupiają uwagę mediów i stają się protagonistami dziennikarskiej relacji. Te zmagania antagonistów i protagonistów przypominają w narracji mediów walkę dobra ze złem, która nie prowadzi wprawdzie do ostatecznego rozwiązania konfliktu, ale już samo ukazanie istoty sporu oraz odpowiednie nazwanie dążeń obu stron (np. poprzez określenia metaforyczne i metonimiczne), „wprowadza do relacji opozycyjne kategorie binarne, stanowiące głęboką strukturę całej opowieści i przypisujące jej ogólniejsze znaczenie mityczne"8. Nadanie przekazom dziennikarskim formuł mitycznych zdolnych szerzyć treści ideologiczne sprzyja, zdaniem Mrozowskiego, umacnianiu lub osłabianiu hegemonii grup dominujących. A ponieważ władza daje lepszy dostęp do mediów, przyczyniają się one do dalszego umocnienia jej hegemonicznej pozycji.

Istotna dla tych rozważań ,teoria hegemonii”, opracowana przez włoskiego marksistę Antonia Gramsciego, mówi, że o uprzywilejowanej pozycji grupy rządzącej decyduje w dużej mierze aprobata mas, które akceptują władzę polityczną i kulturalną klasy dominującej ${ }^{9}$. Hegemonia środowisk rządzących opiera się zatem na zgodzie negocjowanej z resztą społeczeństwa. W wyniku tego „porozumienia” grupy podporządkowane mogą, oczywiście, prezentować swoje interesy, ale „,zwykle w ograniczonym zakresie i wypaczonej postaci, a co najważniejsze [wypowiedzi tych grup - przyp. A. M.] są tak zhierarchizowane, by dyskurs patriarchalnego kapitalizmu zajmował pozycję dominująca, wyznaczająca preferowany sposób odczytania przekazu” ". Zdaniem Mrozowskiego, „wspieranie hegemonii klasy dominującej nie tylko nie musi prowadzić do stronniczości informacji, ale nawet daje się pogodzić z podstawowymi kanonami dziennikarstwa, tzn. obiektywizmem i bezstronnością" ". Kinga Dunin, śledząc konstrukcję dyskursów, mechanizmy ich działania, wewnętrzną dialogo-

M. Mrozowski, Media masowe ..., op. cit., s. 318.

8 Ibidem, s. 319. Metafory i metonimie nadają przekazowi charakter symboliczny. Przy ich pomocy opowieść jest przekształcana w mit bądź uruchomiony zostaje ciąg skojarzeń wiążących opowieść z jakąś strukturą mityczną.

9 A. Gramsci, Selections From the Prison Notebooks, London 1971. Cyt. za:

D. Strinati, Wprowadzenie do kultury popularnej, przeł. W. J. Burszta, Poznań 1998, s. $131-142$.

10 M. Mrozowski, Media masowe ..., op. cit., s. 219.

11 Ibidem, s. 222. 
wość oraz produkcję sensów, zwraca jednak uwagę, że to „w ramach dyskursu dominującego ustalane są hierarchie ważności. Które poglądy są istotne, a które mogą być [...] prezentowane jedynie na marginesie jako dziwactwo lub ciekawostka" ${ }^{2}$. Media, budujące mityczny obraz świata poprzez selekcję zdarzeń oraz sposób opowiadania o nich, stoją przecież na straży prawomocności dyskursu dominującego. To właśnie komentarz dziennikarski przyczynia się zwykle do uporządkowania rzeczywistości: dowodzi, że zdarzeniami rządzi konkretna logika, zaś ludzkie działania mają określony sens ${ }^{13}$.

Te uwagi o „mitycznej formule” wypowiedzi dziennikarskich oraz ich funkcjonowaniu w szerszym kontekście politycznej, społecznej i kulturalnej w ła d zy grup (dyskursów) dominujących nad podporządkowanymi posłużą mi w ustaleniu reguł obecności feministek w mediach. Strukturalistyczna analiza dyskursu dziennikarskiego prowadzi do wyeksponowania roli mediów jako „tłumacza” i interpretatora zdarzeń w kategoriach mitycznych. Feministki są tu częścią mitu: pełnią funkcję antagonisty. W takim ujęciu tylko media mają prawo do opowiadania historii, zaś feministki są jednym z jej „elementów”. Według Włodzimierza Proppa, autora słynnej Morfologii bajki, kulminacyjnym punktem każdej opowieści jest „walka” między „bohaterem” a ,antagonistą”, zakończona porażką tego ostatniego. Antagonista jest bowiem ,przeciwnikiem wyrządzającym szkodę. Jego rola polega na zakłóceniu spokoju [...], wywołaniu jakiegoś nieszczęścia, wyrządzeniu krzywdy"14.

Poststrukturalistyczne teorie Barthes'a, Foucaulta czy Derridy pozwalają rozważyć relacje mediów i feministek w kontekście „władzy dyskursu". W tym rozumieniu dziennikarze reprezentują grupy dominujące: artykułując ich stanowisko, stają się siłą współodpowiedzialną za kształt systemu patriarchalnego ${ }^{15}$ (zgodnie z twierdzeniem McLuhana, że „prze-

12 K. Dunin, Karoca z dyni, Warszawa 2000, s. 36.

13 M. Mrozowski, Media masowe ..., op. cit., s. 317.

14 W. Propp, Morfologia bajki, przeł. W. Wojtyga-Zagórska, Warszawa 1976, S. 100 .

15 Rozważam tu przypadek mediów komercyjnych i publicznych „głównego nurtu" (tzw. mainstream), które mają największą siłę oddziaływania społeczno-politycznego. Pomijam wszelkie media niekomercyjne (non-profit), stanowiące integralną część szerszych struktur organizacyjnych, takich jak: partie polityczne, kościoły, związki zawodowe itp. Więcej na temat różnych instytucji nadawczych pisze M. Mrozowski, Media masowe ..., op. cit., s. 46-49. 
kaźnik jest przekazem”"16). Natomiast dyskurs feministyczny to „wypowiedź Innego", głos opresjonowanych w patriarchacie kobiet - wykluczonych ze sfery wpływów i władzy, ale także z symbolicznej przestrzeni języka. Jak pisze Barthes, ,jedną z najbardziej typowych cech każdej drobnomieszczańskiej mitologii jest niemożność wyobrażenia sobie Innego. Odmienność jest pojęciem najbardziej nieprzystającym do zdrowego rozsądku"17.

W tym ujęciu feministki są „Innym”, który żąda prawa głosu. Jeśli bowiem prawdą jest rozpad „wielkich narracji”, ogłoszony przez Lyotarda i innych postmodernistów, to powstałą lukę można teraz z powodzeniem zapełnić własną w e r s j ą opowieści. W takim rozumieniu dyskurs dziennikarski nie jest już jedynym, lecz tylko jednym z możliwych dyskursów; feministki mają prawo do swojej opowieści (choć oczywiście nie mają medium): „Nadrzędne kategorie [...] - Rozum, Prawda, Natura Ludzka, Historia, Tradycja - zastępuje się teraz pytaniami odnoszącymi się do aspektów historycznych i społecznych: »C z y ja prawda? C z y j a natura? C z y j a wersja rozumu? C z yj a historia? C z yj a tradycja? «"18.

$\mathrm{Z}$ analizy strukturalistycznej wynika, że formuła mityczna pojawiła się w dziennikarskiej opowieści o feministkach już w XIX wieku. W narracji mediów rola antagonisty przypadła sufrażystkom ${ }^{19}$, dążącym poprzez

16 M. McLuhan, Środek jest przekazem, w: tegoż, Wybór tekstów, przeł. E. Różalska, J. M. Stokłosa, Poznań 2001, s. 212.

17 R. Barthes, Mitologie, op. cit., s. 65. O wykluczeniu feministek z dziennikarskiej relacji pisze Agnieszka Graff w swojej książce Świat bez kobiet. Płeć w polskim życiu publicznym, Warszawa 2001 (rozdział: Dlaczego nikt nie lubi feministek?, s. 208-232).

18 J. Bator, Feminizm, postmodernizm, psychoanaliza: filozoficzne dylematy feministek ,drugiej fali”, Gdańsk 2001, s. 34-35.

19 Mianem ,sufrażystek” bądź ,,emancypantek” określam tu feministki tzw., ,pierwszej fali", których głównym celem było wywalczenie dla kobiet prawa głosu. Miriam Schneir w pierwszym tomie swojej antologii Feminism: The Essential Historical Writings (New York 1994) zwraca uwagę, że w Stanach Zjednoczonych ,pierwsza fala" narodziła się w 1848 roku na konwencji w Seneca Falls, podczas której odczytano kluczową dla ruchu kobiecego Declaration of Sentiments, wzorowaną na Deklaracji Niepodległości. Koniec sufrażyzmu w Ameryce wyznacza rok 1920 i przyjęcie XIX poprawki przyznającej kobietom prawa wyborcze. W Polsce początek ,pierwszej fali" feminizmu przypadł na lata 1860-te, kiedy to pojawiło się pokolenie kobiet świadomie walczących o równe prawa polityczne. Aneta Górnicka-Boratyńska w pracy Stańmy się sobq. Cztery projekty emancypacji (1863-1939) (Izabelin 2001) jako datę zamykającą polski ruch emancypacyjny podaje rok 1939, „który realnie i symbolicznie zamyka całą epokę historyczną i kulturową" (s. 6). Więcej o feministycznych fa- 
pewne „rewolucyjne” działania (np. manifestacje, pikiety, zbieranie petycji) do zmiany stosunków między płciami w społeczeństwie patriarchalnym. Ponieważ w XIX wieku prasa była ważnym narzędziem władzy w męskich rękach, stosunek wydawców do tzw. „kwestii kobiecej” był raczej niechętny. Oprócz wyraźnego wyśmiewania sufrażystek i ostrej krytyki pod ich adresem, prasa stosowała także „,zabieg przemilczenia”, który automatycznie eliminował dyskurs emancypacyjny ze świadomości spo$ł_{\text {łecznej }}^{20}$. W opinii ówczesnych (męskich) polityków, feministki nie były bowiem partnerem $\mathrm{w}$ dyskusji nad kształtem nowoczesnego społeczeństwa. Ich głos był głosem „Innego": kobiety były wykluczone ze sfery publicznej, a ich działalność ograniczała się jedynie do spraw domu, rodziny i wspólnoty religijnej ${ }^{21}$.

Media i kultura popularna wykreowały zatem pewien nośny stereotyp feministki będącej antytezą ,,prawdziwej” kobiety: „Feministka jest pełna jadu, mocno podlanego intelektualizmem. Ona dużo czyta, dużo wie, w racjonalizowaniu bije na głowę [...] mężczyzn (oraz niektóre kobiety)",22 - czytamy w znanej i lubianej polskiej powieści sprzed kilku lat. Elaine Showalter, literaturo- i kulturoznawczyni, zwraca uwagę, że już w latach 1880-tych politycy i dziennikarze patrzyli na sufrażystki niczym na ,agentki pozaziemskiego świata, które wywoływały tylko gniew i cierpienie" ${ }^{, 23}$. Stereotyp feministki, który pojawił się w tym okresie w prasie i literaturze pięknej, łączył w sobie satyryczny wizerunek lesbijki, histeryczki, starej panny i przemawiającej na wiecach „męskiej” kobiety, całkowicie pozbawionej delikatności i kobiecego wdzięku ${ }^{24}$. Stereotyp ten działał zarówno w wiktoriańskiej Ameryce, jak i w XX wieku, odstra-

lach pisze Maggie Humm, Słownik teorii feministycznej, przeł. J. Mikos i B. Umińska, Warszawa 1993, a także Kazimierz Ślęczka, Feminizm: ideologie i koncepcje społeczne współczesnego feminizmu, Katowice 1999.

20 S. D. Hoffert, When Hens Crow: The Women's Rights Movement in Antebellum America, Bloomington 1995, s. 11-13.

21 B. Welter, The Cult of True Womanhood: 1820-1860, w: The American Family in Social-Historical Perspective, pod red. M. Gordon, New York 1978, s. 313-333.

22 K. Grochola, Nigdy w życiu, Warszawa 2001, s. 271. O stereotypie feministki u Grocholi pisze A. Graff w książce Świat bez kobiet ..., op. cit., s. 208-232.

23 E. Showalter, Sexual Anarchy. Gender and Culture at the Fin de Siècle, London 1991, s. 7, przeł. A.M.

24 Showalter podaje przykład powieści Henry’ego Jamesa The Bostonians (1886) oraz George'a Gissinga The Odd Women (1891), w których pojawiają się postaci „histerycznych feministek". 
szając kobiety od aktywności w organizacjach feministycznych (a tym samym w polityce): „Psychiatrzy przeciwstawiali zdrowej, oddanej, patriotycznej matce i żonie neurotyczną i natarczywą feministkę, której determinacja, by rujnować życie innych kobiet, wywodziła się z jej własnej chorej niemożności osiągnięcia kobiecego spełnienia"25.

W swojej opowieści o ruchu kobiecym media częściej skupiały się na wyglądzie zewnętrznym czy faktach z życia prywatnego feministek niż na głoszonych przez nie hasłach. Był to wyraz lekceważenia feminizmu jako ruchu społeczno-politycznego, o którym dziennikarze mówili chętnie, ale raczej w kontekście tzw. „reformy stroju”: sufrażystki wywalczyły dla kobiet prawo do noszenia spodni, zaś feministki „drugiej fali” demonstracyjnie spaliły staniki ${ }^{26}$. Prowadząc narrację w duchu trywializacji postulatów feminizmu poprzez zredukowanie ich do sfery prywatnej (łączonej z tym, co kobiece), dziennikarze (czy też: stojący za nimi nadawcy) sygnalizowali jednocześnie nienaruszalność porządku w sferze publicznej, a więc tam, gdzie dochodzi do dystrybucji władzy.

Zdaniem Agnieszki Graff, obserwującej tryb mówienia polskich mediów o ruchu kobiecym, feministki do dziś egzystują w dziennikarskich relacjach na ,prawach wariata”, którego albo nie dopuszcza się do głosu, albo zamyka w getcie, bądź ostatecznie ,przeciwstawia się go wariatowi innego rodzaju, a norma pojawi się sama, gdzieś pośrodku"27. T. D. Nelson, autor Psychologii uprzedzeń, zwraca uwagę na olbrzymią rolę mediów w kreowaniu i podtrzymywaniu stereotypów, a zarazem na udział dziennikarzy w budowaniu dystansu wobec szeroko pojętej „inności”. Jego zdaniem, media tworzą wizję świata funkcjonującego w sieci binarnych opozycji, a stereotypy ułatwiają rozeznanie w tym świecie: pomagają porządkować informacje i kategoryzować zjawiska ${ }^{28}$.

Analiza strukturalistyczna formuły mitycznej, za pomocą której dziennikarze wyrażają ,prawdę" o świecie (w tym również o ruchu feministycznym), pokazuje, że media mają swoisty monopol na opowiadanie historii: są „opowiadaczem” (a więc także interpretatorem) mitu. Segre-

25 R. Rosen, The World Split Open. How the Modern Women's Movement Changed America, New York 2000, s. 27, przeł. A.M.

26 O reformie stroju kobiecego i tzw. „Bloomersach” pisze szerzej Sylvia D. Hoffert, When Hens Crow ..., op. cit., s. 22-31. O legendzie „spalonego stanika” wspomina Ruth Rosen, The World Split Open ..., op. cit., s. 160-161, a także Susan Brownmiller, In Our Time. Memoir of a Revolution, New York 2000, s. 37.

27 A. Graff, Świat bez kobiet ..., op. cit., s. 103-109.

28 T. D. Nelson, Psychologia uprzedzeń, przeł. A. Nowak, Gdańsk 2003, s. 62-63. 
gując zdarzenia i wpisując je w określoną strukturę narracyjną, gdzie jedne głosy są lepiej słyszalne i de facto ważniejsze niż inne, media występują jako strona współodpowiedzialna za dystrybucję władzy i autorytetu. „Przysługujące” reporterom prawo komentarza, za pomocą którego wpływają oni znacząco na opinie odbiorców, jest w istocie silnym narzędziem w ideologicznej walce. Feministki są w tej wersji mitu antagonistą, „Innym": reprezentują to, co „złe” dla porządku świata (patriarchalnego). Dlatego ich działania są napiętnowane: pomijane milczeniem, ośmieszane lub marginalizowane. Za każdym razem jest to jakaś forma wykluczenia, bo ,inny człowiek jako ten Inny nie jest tylko jakimś alter ego. Jest on tym, czym ja nie jestem. Jest on tym nie z racji swego charakteru lub fizjonomii czy swojej psychiki, ale z racji samej swej Inności"29.

Poststrukturalizm i inne teorie literackie weryfikują opowiedzianą przez media mityczną formułę relacji o ruchu feministycznym, pozwalając zobaczyć tę historię w szerszym kontekście „,władzy dyskursu”. Michel Foucault wyjaśnia w Archeologii wiedzy, że w każdym dyskursie tkwi w pewnym sensie ,potencjał władzy”. Dzieje się tak dlatego, że żaden dyskurs nie jest w istocie neutralny, przezroczysty i uniwersalny. Dyskurs nie istnieje sam dla siebie, ale w sieci innych dyskursów, z którymi, chcąc czy nie chcąc, prowadzi dialog. Pomiędzy dyskursami toczy się walka o władzę: symboliczna - o prawo do opowiedzenia własnej historii, ale również realna - o kontrolę nad sferą publiczną. Przegrana w tej walce oznacza wykluczenie: „W każdym społeczeństwie »produkcja« dyskursu jest kontrolowana oraz podlega selekcji drogą "pewnej liczby procedur«, takich jak na przykład procedura ekskluzji, czyli szeroko pojętego zaka$\mathrm{zu}^{\prime 30}$. W rozumieniu Foucaulta istnieją tylko dyskursy uwikłane w sieć zależności. Wszystko jest tekstem i ,wszystko już jest interpretacją [...]. Stosunek objawiający się wewnątrz interpretacji zakorzeniony jest tyleż w przemocy, co w intencji wyjaśniania"31.

Zależność pomiędzy wiedza, władzą i dyskursem, będącą przedmiotem opisu poststrukturalistów Barthes'a, Foucaulta czy Derridy, analizuje również, w odniesieniu do narracji historycznej, Hayden White, badacz ze szkoły nowych historyków. White zwraca uwagę, że z pewnego rodzaju

29 E. Lévinas, Czas i to, co inne, przeł. J. Migasiński, Warszawa 1999, s. 93.

30 M. Foucault, L'Ordre du discours, s. 10-11. Cyt. za: J. Topolski, Wstęp, w: M. Foucault, Archeologia wiedzy, op. cit., s. 18.

31 M. Foucault, Nietzsche, Freud, Marks, przeł. K. Matuszewski, „Literatura na Świecie" 1988, nr 6, s. 258. 
subiektywnością zapisu (i odczytu) mamy do czynienia również w tekstach historycznych, a więc uznawanych dotąd za „prawdziwe”. Począwszy od selekcji epizodów, poprzez kolejność ich przedstawienia, aż po wybór schematu fabularnego (satyra, tragedia, romans, komedia) i tropów stylistycznych (ironia, metonimia, metafora, synekdocha) narracja historyczna prezentuje pewną określoną wersję wydarzeń, w której jedne zagadnienia są odpowiednio wyeksponowane, zaś inne - przemilczane. Jak w każdym innym dyskursie, tak i w opowieści historycznej chodzi o władzę i utrzymanie porządku:

„[...] narracja w ogóle - od baśni ludowej do powieści, od rocznika do
w pełni rozwiniętej »historii« - ma związek z zagadnieniami prawa,
prawowitości i prawomocności, czy też ogólniej, władzy i autorytetu.
[...] wartość przypisywana narracyjnemu przedstawianiu rzeczywi-
stych zdarzeń wynika z pragnienia, by zdarzenia te prezentowały spój-
ność, integralność, pełnię i kompletność obrazu życia [...]”32.

Feministki pojawiają się w mediach jako „Inny”, obcy. Przemawiają w imieniu grup ,podporządkowanych": kobiet, ale także innych mniejszości (rasowych, etnicznych, seksualnych); opowiadają się po stronie różnicy i odmienności. Krytykując fallocentryzm współczesnego świata, żądają „przyswojenia tego, co »kobiece«, ponieważ to, co »męskie« ma już swoje miejsce"33. W opinii dziennikarzy, argumenty feministek są „skażone ideologią", stronnicze, subiektywne, nienaukowe i jako takie nie mogą być rozpatrywane w kategorii uniwersalnej „,prawdy”. W tekst dziennikarski, który skierowany jest do odbiorcy jako do „swojego”, wpisana jest zatem jego programowa obcość wobec feminizmu.

Tymczasem Agnieszka Graff zwraca uwagę, że nazwanie czyichś poglądów ,ideologią" - zwłaszcza we współczesnej Polsce - ma na celu zdyskredytowanie ich w oczach odbiorcy; jest to zabieg o charakterze wykluczającym ${ }^{34}$. Jednak żaden dyskurs (także dziennikarski) nie jest wolny od ideologii, nie jest neutralny, bezinteresowny, przezroczysty. Język

32 H. White, Znaczenie narracyjności dla przedstawienia rzeczywistości, przeł. M. Wilczyński, w: H. White, Poetyka pisarstwa historycznego, pod red. E. Domańskiej i M. Wilczyńskiego, Kraków 2000, s. 153, 169. Por. też: K. J. Gergen, M. M. Gergen, Narrative and the Self as Relationship, w: Refiguring the Self and Psychology, pod red. K. J. Gergen, Dartmouth 1993, s. 201-240.

33 G. Borkowska, Cudzoziemki. Studia o polskiej prozie kobiecej, Warszawa 1996, s. 201-202.

34 A. Graff, Feminizm na rozstajach: między polityka, kulturq a nauka, op. cit., s. 215-219. 
zawsze wartościuje i kategoryzuje; jest narzędziem władzy lub próbą oporu. Mówimy, bo czegoś chcemy; nie istnieje „czysta” komunikacja. Feministki powołują się na poststrukturalistów, którzy udowodnili, że wiedza zawsze jest skażona ideologią: nie można mówić o obiektywizmie dyskursu, a jedynie o innej opcji politycznej lub innym światopoglądzie bada$\mathrm{cza}^{35}$. Przypominają Foucaultowską sieć zależności między wiedzą, władzą i dyskursem: pojęcie „odmiany dyskursu”, zależnego od stosunku do porządku władzy, to w istocie klucz do analizy faktu, dlaczego niektóre odmiany dyskursu stają się ważniejsze od innych i dlaczego kobiety zajmują podrzędną pozycję w systemie językowym ${ }^{36}$.

\section{Koniec ,wielkiej opowieści”? Feministyczna de(kon)strukcja męskiego świata}

Feminizm, którego istotą jest krytyka systemu patriarchalnego w jego społeczno-politycznym wymiarze, jak również negacja męskocentrycznej kultury i oświeceniowego myślenia o świecie w kategoriach Rozumu i Prawdy, przyczynił się znacząco do zakwestionowania modernistycznych kategorii poznawczych: neutralnego dyskursu, uniwersalnego podmiotu i jednej historii. Zdaniem feministek, na naszych oczach rozpadła się oświeceniowa narracja o wspólnym racjonalnym dążeniu emancypacyjnym ludzkości. „Wielka opowieść”, by powołać się raz jeszcze na Lyo$\operatorname{tarda}^{37}$, o powszechnym dostępie do „królestwa wiedzy i rozumu” okazała się fikcją, gdyż kluczowa dla tej historii „liberalna definicja człowieka pomi[nęła] żeńską połowę ludzkości" ${ }^{\text {38 }}$. Feministki udowadniają, że tak w sferze polityki, jak i w sferze kultury mamy do czynienia $\mathrm{z}$,językiem zachodniej, zwłaszcza zaś greckiej męskości”39. Grecka wspólnota usta-

35 E. Domańska, Wokót metahistorii, wstęp do: H. White, Poetyka pisarstwa ..., op. cit., s. 27.

36 J. Bator, Feminizm i postmodernizm - powinowactwo z wyboru?, w: Różnica i różnorodność. O kulturze ponowoczesnej - szkice krytyczne, pod red. A. Jawłowskiej, Warszawa 1996, s. 95.

37 J.-F. Lyotard, Kondycja ponowoczesna, przeł. M. Kowalska i J. Migasiński, Warszawa 1997.

38 J. Bator, Feminizm, postmodernizm, psychoanaliza ..., op. cit., s. 33.

39 M. Środa, Indywidualizm i jego krytycy. Współczesne spory między liberałami, komunitarianami i feministkami na temat podmiotu, wspólnoty i ptci, Warszawa 2003, s. 313. 
nowiła pewien wzorzec dla społeczeństw demokratycznych, jednak u jej podstaw legło realne wykluczenie kobiet z polityki, a także wykluczenie symboliczne $-\mathrm{z}$ języka.

W Oświeceniu, mówią feministki, uznawanym za wiek Rozumu i „wyjścia człowieka ze stanu małoletności" ${ }^{40}$, kobiety miały szansę wydostać się z greckiego modelu demokracji opartej na wykluczeniu. Mogły wydobyć się z milczenia i stać się pełnoprawnymi członkiniami społeczeństwa, a tym samym wywalczyć sobie własne miejsce w nowożytnym dyskursie. Tak się jednak nie stało, gdyż podstawą polityki liberalnej nowoczesnego państwa jest, jak zwraca uwagę Carole Pateman, zasada rozdzielenia sfery publicznej i prywatnej. W trakcie zawiązywania umowy jednostki przechodzą wprawdzie ze stanu natury w stan uspołecznienia (społeczeństwo obywatelskie), zaś powołana w tym procesie władza ma za zadanie chronić wspólne dobra (wolność, równość i uprawnienia), jednak analiza dzieł nowożytnych liberałów (Locke'a, Hobbesa, Benthama), przeprowadzona przez Pateman, dowodzi, że umowa społeczna pomija kobiety ${ }^{41}$. Ze względu na ,swą szczególną bliskość naturze”, o której mówił już Arystoteles $^{42}$, kobiety zostają automatycznie przypisane do sfery prywatnej (rodzina) i wykluczone ze sfery publicznej: decyzji i wpływów:

„Poddaństwo kobiet - jak pisze Pateman - dzięki temu podziałowi zostaje ukryte w świecie pozornie egalitarnym, opartym na bezstronnych procedurach gwarantujących uniwersalistyczne fundamenty. Tymczasem jest to podział dokonany jedynie w obrębie świata męskiego: mężczyźni poruszają się swobodnie po obu sferach, miejsce kobiet jest praktycznie ograniczone tylko do jednej - prywatnej",33.

Zepchnięcie kobiet do sfery prywatnej, usankcjonowane w Oświeceniu, zdecydowało, zdaniem feministek, o kształcie modernistycznej opowieści, której oś konstrukcyjną wyznaczyła siatka binarnych opozycji:

40 I. Kant, Co to jest Oświecenie?, przeł. A. Landman, w: T. Kroński, Kant, Warszawa 1966, s. 164.

41 C. Pateman, Feminist Critique of the Public/Private Dichotomy, w: tejże, The Disorder of Women. Democracy, Feminism and Political Theory, Stanford, California 1989 , s. $118-140$.

${ }_{42}$ M. Środa, Indywidualizm i jego krytycy ..., op. cit., s. 299.

43 Ibidem, s. 306. Pateman zwraca uwagę, że kobiety były tradycyjnie postrzegane jako „figury nieporządku”, ,potencjalne zagrożenie dla granic męskiego systemu”, „część chaosu”, „mieszkanki tajemniczej i przerażająco dzikiej strefy na marginesie kultury patriarchalnej". Por. C. Pateman, »The Disorder of Women«: Women, Love, and the Sense of Justice, w: tejże: The Disorder of Women ..., op. cit., s. 17-29. 
publiczne/prywatne, kultura/natura, mężczyzna/kobieta, dobro/zło itd. Elementy tych opozycji odnajdujemy również w dziennikarskiej (mitycznej) formule opowieści o ruchu feministycznym ${ }^{44}$. Feministki podkreślają, że brak dostępu do sfery publicznej przyczynił się nie tylko do realnego odsunięcia kobiet od władzy (tę kwestię poruszają głównie feministki amerykańskie: liberalne i radykalne ${ }^{45}$ ), ale przede wszystkim do ich symbolicznego wykluczenia z języka (piszą o tym przede wszystkim Francuzki z kręgu tzw. „nowej różnicy”"46). Dlatego dzisiaj (niektóre) feministki odrzucają modernistyczny projekt emancypacji, ze względu na jego fallogocentryczny charakter.

W ujęciu Elizabeth Grosz „fallogocentryzm to seria dyskursywnych procedur, strategia wtłaczająca reprezentacje każdej z płci w jeden model nazywany modelem »człowieczym« czy »ludzkim «, który w istocie odpowiada temu, co męskie. Fallogocentryzm to ukryta u podstaw kultury uniwersalizacja tego, co męskie, stłumienie kobiecego głosu, reprezentacji, istnienia" $^{\text {"47 }}$. Feministki dowodzą, że w oświeceniowej narracji o wspólnej emancypacji wszystkich ludzi zabrakło de facto kobiecego głosu. Zabrakło go na tak długo, że ludzkość zapomniała o kobiecym wymiarze swojego doświadczenia. Nowożytna opowieść o emancypacji ma zatem tylko jeden podmiot i prezentuje jeden punkt widzenia - męski. W modernistycznym dyskursie wykluczona kobiecość stała się symbolem „Innego", niemożliwej do wyrażenia różnicy.

Feministki są zgodne, że podział na sferę publiczną i prywatną zdecydował o opresji kobiet w społeczno-politycznej rzeczywistości patriarchatu oraz symbolicznej represji tego, co kobiece, w języku. Różnice między nimi pojawiają się wraz z próbą ustosunkowania się do tej niekorzystnej dla kobiet sytuacji. Od czasów Mary Wollstonecraft, autorki $A$ Vindication of the Rights of Woman (1792), feministki poszukują niejako „kobiecej wersji” opowieści o emancypacji i usiłują znaleźć dla kobiet miejsce

44 Por. M. Mrozowski, Media masowe ..., op. cit., s. 320.

45 Por. np.: Z. Eisenstein, Radical Furture of Liberal Feminism, Boston 1986; Feminism, the Public and the Private, pod red. J. B. Landes, Oxford 1998; R. Putnam Tong, Myśl feministyczna. Wprowadzenie, przeł. J. Mikos, B. Umińska, Warszawa 2002.

46 Por. np.: J. Bator, Feminizm, postmodernizm, psychoanaliza ..., op. cit.; E. Hyży, Kobieta, ciało, tożsamość. Teorie podmiotu w filozofii feministycznej końca XX wieku, Kraków 2003.

47 E. Grosz, The In(ter)vention of Feminist Knowledge; cyt. za: J. Bator, Feminizm, postmodernizm, psychoanaliza ..., op. cit., s. 47. 
w sferze publicznej. Obok koncepcji liberalnej (prezentowanej na przykład przez Betty Friedan ${ }^{48}$ ), w myśl której kobiety powinny wejść do sfery publicznej na takich samych prawach jak mężczyźni (feminizm równości), wymienia się propozycje feministek różnicy - z silnym naciskiem na kobiece wartości (np. Carol Gilligan w pracy In a Different Voice (1982) dokonuje wyraźnego rozróżnienia pomiędzy „etyką kobiecą”, opartą na miłości i trosce o dobro innych, a „etyką męską”, skupioną wokół sprawiedliwości, prawa, niezależności ${ }^{49}$ ). Pateman określa trudności z wyartykułowaniem kobiecej tożsamości w sferze publicznej mianem „dylematu Wollstonecraft": z jednej strony kobiety chcą prawa do obywatelstwa na równych zasadach z mężczyznami, zaś z drugiej strony dostrzegają swoją odmienność: inne talenty, potrzeby, niepokoje, które odróżniają ich aktywność od męskiej działalności ${ }^{50}$.

Wejście kobiet do sfery publicznej na „męskich zasadach” wiąże się z niebezpieczeństwem akceptacji modernistycznego dyskursu emancypacyjnego, a więc męskiego podmiotu, pozornie neutralnego (a w rzeczywistości fallokratycznego) języka itp.: „Płeć męska - pisze Georg Simmel nie góruje po prostu nad żeńska, lecz staje się czymś ogólnoludzkim, normującym w równej mierze przejawy jednostkowej męskości, jak i żeńskości - tendencja ta zasadza się, poprzez różne formy pośrednie, na silniejszej pozycji mężczyzn" ${ }^{, 1}$. Susan J. Hekman stwierdza, że fallokratyczny język nie daje kobietom wielu możliwości: jeśli chcą wejść do męskiej sfery racjonalności, muszą mówić jak mężczyźni (a więc nie swoim głosem), zaś pozostając przy „kobiecym języku”, skazane są na irracjonalność lub milczenie ${ }^{52}$.

Stąd tak ważne jest dla feministek ustalenie zasad (i wyznaczenie granic) obecności kobiet w języku. Poszukując własnego głosu, feministki tropią ślady kobiecej reprezentacji w świecie. Ten „własny głos” kobiet odnajdujemy $\mathrm{w}$ - proponowanych przez feministki - żeńskich końcówkach nazw zawodów uznawanych dotąd za męskie, w zachowanych pa-

48 Mam tu na myśli głównie ,wczesną” Friedan, The Feminine Mystique, New York 1963.

49 C. Gilligan, In a Different Voice. Psychological Theory and Women's Development, Cambridge 1982, s. 30.

50 C. Pateman, The Patriarchal Welfare State, w: tejże, The Disorder of Women ..., op. cit., s. 197.

${ }^{51}$ G. Simmel, On Women, Sexuality and Love; cyt. za: M. Środa, Indywidualizm i jego krytycy ..., op. cit., s. 227.

52 S. J. Hekman, Gender and Knowledge. Elements of Postmodern Feminism; cyt. za: J. Bator, Feminizm, postmodernizm, psychoanaliza ..., op. cit., s. 38. 
nieńskich nazwiskach mężatek, w „upłciowieniu” tekstów naukowych, których ,programowy” obiektywizm maskował dotąd męski punkt widzenia. Feministki krytykują zarówno jawny seksizm w języku (jawną dyskryminację), jak i pozorną neutralność dyskursu, twierdząc, że uniwersalizacja sprzyja w istocie marginalizacji pewnych zjawisk, które nie mieszczą się w nurcie dominującym ${ }^{53}$. Zdaniem Stanleya Fisha, nie można dzisiaj lekceważyć wysiłków feministek, ponieważ przeprowadzona przez nie krytyka fallogocentryzmu przyczyniła się do bardziej świadomej refleksji nad językiem i kulturą: „To nie moc teorii feministycznej, czy też nawet pozornie teoretycznych haseł (»to, co osobiste, jest tym, co polityczne«, »płeć jest społeczną konstrukcją«) wywarły takie wrażenie na wszystkich, lecz niemożność uniknięcia feministycznych sposobów myślenia nawet wtedy, gdy się je odrzuca"54.

Agnieszka Graff, powołując się na teorie poststrukturalistów, podkreśla, że język zawsze wartościuje, a podstawową strategią feminizmu jest ujawnianie i ośmieszanie antykobiecego „skrzywienia” języka (np. przez odwrócenie parodystyczne). To wartościowanie jest obecne w stylu wypowiedzi, formach przytoczen, gestach retorycznych, elementach pozatekstowych itp. W samym już podjęciu jakiegoś tematu lub jego przemilczeniu kryje się element wartościowania ${ }^{55}$. Język jest częścią systemu władzy: istnieje nierozerwalny związek między sposobem myślenia i mówienia o świecie oraz funkcjonowania (działania) w nim. Zwraca na to uwagę John L. Austin, twórca koncepcji aktów mowy: „Wygłoszenie wypowiedzi jest wykonaniem jakiejś czynności, jest czymś, o czym nie myśli się normalnie,

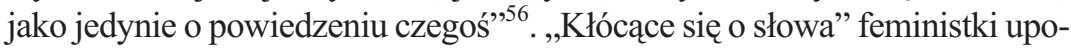
minają się zatem o prawo do reprezentacji kobiet w języku i świecie.

Próby „reformy” języka, uwzględniające doświadczenie kobiet, podejmowane były od początku istnienia ruchu feministycznego. W tekstach Mary Wollstonecraft, Margaret Fuller, Elizabeth Cady Stanton, Lucretii Mott, Betty Friedan i wielu innych pojawia się żądanie prawa do mówienia „własnym głosem”, wezwanie do „przerwania kobiecego milczenia”,

53 Por. A. P. Nilsen, Sexism in English: A 1990s Update, w: Reading Women's Lives: An Introduction to Women's Studies, Ohio 1997, s. 185-198.

54 S. Fish, Drogq antyformalistycznq aż do końca, przeł. A. Szahaj, w: S. Fish, Interpretacja, retoryka, poetyka. Eseje wybrane, pod red. A. Szahaja, wstęp R. Rorty, Kraków 2002, s. 170.

55 A. Graff, Feminizm na rozstajach ..., op. cit., s. 216.

56 J. L. Austin, Jak działać słowami, w: tegoż, Mówienie i poznawanie. Rozprawy $i$ wykłady filozoficzne, przeł. B. Chwedeńczuk, Warszawa 1993, s. 555. 
postulat „nazwania niewypowiedzianego" doświadczenia kobiet. Agnieszka Graff podkreśla, że feminizm jest przede wszystkim praktyką dekonstruującą kulturę patriarchalną, w tym językowy obraz świata. Nazwanie bowiem pewnych zjawisk (np. seksizm, szowinizm, opresja czy dyskryminacja kobiet), skłania do refleksji nad nimi, zaś namysł nad językiem może stać się podstawą zmiany myślenia o świecie ${ }^{57}$.

Feministyczna narracja, zaczynająca się zwykle od indywidualnego „przebudzenia”, „zdziwienia”, „gniewu”, stopniowo poszerza zasięg swego oddziaływania: staje się opowieścią o wykluczeniu kobiet z historii, polityki i kultury. Krytykując fallogocentryzm, feministki odrzucają pewien system zachowań politycznych, społecznych, kulturowych itp., oparty na eliminowaniu kobiet ze sfery władzy i wpływów. Nie zgadzają się z modernistyczną wersją opowieści o emancypacji ludzkości i nastaniu ery Rozumu, twierdząc, że uniwersalność i neutralność oświeceniowej narracji jest pozorna i służy interesom grup dominujących, ze szkodą dla wszelkiej odmienności, różnicy, mniejszości. Feministyczne spory dotyczą przede wszystkim dróg wyjścia z tej niepożądanej sytuacji.

\section{3. „Monologi waginy”: w poszukiwaniu świata (dla) kobiet}

Feministki nie są w swoich działaniach zupełnie bezkrytyczne. Pojawiają się wewnętrzne tarcia i spory, nieustannie rodzą się wątpliwości. Podziały w obrębie ruchu feministycznego przebiegają w wielu różnych kierunkach w zależności od przekonań politycznych, religijnych, filozofii czy metod badawczych, a także od rejonu świata, kultury, orientacji seksualnej itd. Właśnie ta różnorodność poglądów jest tak istotna, gdy mówimy o feminizmie. Wywołując „ferment twórczy”, feministki nie stoją w miejscu. Ich koncepcje przynoszą wprawdzie (na razie) więcej pytań niż odpowiedzi, ale taki układ zapobiega skostnieniu ruchu i uniemożliwia stworzenie jednego „obowiązującego” programu.

57 Agnieszka Graff analizuje dyskurs amerykańskich aktywistek ,pierwszej”, „drugiej” i ,trzeciej fali”. Zwraca przy tym uwagę na różnice w sposobie pisania o świecie i postulowania zmian, obecne w tekstach feministek różnych generacji. Szczególnie widoczny jest rozdźwięk między optymizmem feministek „drugiej fali” a „znużeniem”, ,ironicznym dystansem” i ,autorefleksją” feministek „trzeciej fali”. Por. A. Graff, Refusing to Smell the Roses: American Feminism as a Rhetorical Practice (w druku). O feministycznym postulacie zmian w języku pisze też F. R. Shapiro, $\mathrm{Hi}$ storical Notes on the Vocabulary of the Women's Movement, American Speech, vol. 60, Issue 1, Spring 1985, s. 3-16. 
Demaskując fallokratyczny charakter kultury patriarchalnej, feministki nie ograniczają się wyłącznie do krytyki. Przedstawiają różne koncepcje „,naprawy” współczesnego świata. W dziedzinie stosunków społeczno-politycznych proponują zwiększenie udziału kobiet w życiu publicznym, zacieranie podziału między sferą prywatną i publiczną, akceptację inności. Według Toril Moi, norweskiej feministki, ,feminizm jest przede wszystkim dyskursem politycznym, co oznacza, że jest zaangażowany w walkę z patriarchatem i seksizmem. Jest polityczny, gdyż zmierza do zmiany stosunków dominacji między płciami" ${ }^{\text {"58 }}$. Feministki liberalne są zdania, że zmiany te należy przeprowadzić na poziomie regulacji prawnych, zaś feministki radykalne postulują raczej zmianę całego paradygmatu kultury. Pisze o tym Grażyna Borkowska: „Przez feminizację rozumiem nakładanie się kategorii płci na neutralne (pod względem erotycznym) sytuacje kulturowe" ${ }^{99}$. Ta polityczność pozostaje najważniejszą cechą ruchu feministycznego, pokazuje praktyczny wymiar działalności feministek, dowodzi, że cel jest wspólny, a idea - nadal żywa.

Magdalena Środa w swojej pracy Indywidualizm i jego krytycy (2003) pokazuje, że głos feministek staje się coraz wyraźniejszy (i coraz lepiej słyszalny) we współczesnej debacie na temat podmiotu, płci i wspólnoty. Zwraca uwagę, że problemy związane z ustaleniem tożsamości podmiotu-kobiety mogą być spowodowane wielowiekowym marginalizowaniem kobiecego doświadczenia i wykluczeniem kobiet z języka - mówieniem „cudzym głosem”60. Wychodząc od koncepcji Simone de Beauvoir, według której kobieta to „Inny”, nie-mężczyzna, zaś płeć to konstrukt społeczny (kulturowe gender w odróżnieniu od płci biologicznej-sex), przez teorię Kristevej kobiety jako „Braku”, czy Irigaray tezę o kobiecie jako „płci, która nie jest jedna”, feministki - zdaniem Środy - dotarły do szokującego twierdzenia Judith Butler, że „kobieta jako taka nie istnieje" ${ }^{\prime}$. Butler kwestionuje bowiem kluczowe dla feminizmu „drugiej fali” rozróżnienie na płeć biologiczną i kulturową (sex/gender), podkreślając, że płeć biologiczna także jest konstruktem społecznym: ,„Kobiety« to konstrukt historyczny i dyskursywny, zawsze w relacji do innych kategorii,

58 Feminizm jest polityczny. Z Toril Moi rozmawia Małgorzata Walicka-Hueckel, „Teksty Drugie” 1993, nr 4/5/6, s. 97-99.

59 G. Borkowska, Cudzoziemki ..., op. cit., s. 201.

60 Por. M. Środa, Tożsamość bez zróżnicowania, w: tejże, Indywidualizm i jego krytycy ..., op. cit., s. 209-254.

61 J. Mizielińska, »Sen, co kusi...«O kategorii »kobiet« w myśli feministycznej, „Katedra” 2001, nr 1, s. 35. 
które same są zmienne"62. Inspiracją dla Butler jest w pewnym sensie Rorty, który „pokazuje, że problem istnienia bądź nieistnienia danej kategorii to $w$ istocie problem języka opisu, a zatem to, czym istota ludzka jest, nie jest kwestią rozpoznania jakiejś jej prawdziwej esencji, ale sprawą opi-

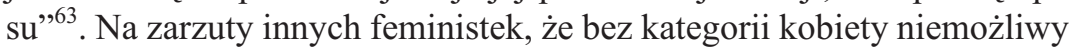
jest dyskurs emancypacyjny, Bulter odpowiada: „Podmiot usytuowany w ramach formacji władza/dyskurs i pozbawiony jakiegokolwiek zewnętrznego odniesienia zachowuje to, co Fraser nazywa »krytyczną zdolnością«. Jako taki może więc angażować się skutecznie w feministyczną batalię, której nie przeszkadza fakt, iż »krytyczna zdolność« jest także kulturowym konstruktem wpisanym w diadę władza/dyskurs"64.

Problemy z ustaleniem definicji kobiety stały się przyczyną jednego z najważniejszych obecnie podziałów wewnątrz ruchu feministycznego. Joanna Bator wspomina o dwóch zwalczających się odłamach feminizmu - kulturowym i postmodernistycznym - wyodrębnionych w toku dyskusji nad kategorią kobiecości i męskości. Feministki kulturowe (np. Mary Daly) wierzą w naturę kobiety i podejmują ciągłe próby opisu jej esencji. Przedmiotem badań kulturowych feministek jest kobiece ciało - symbol prokreacji i stłumionej twórczości. Natomiast według feministek postmodernistycznych (np. Butler, Kristeva, Irigaray, Cixous) kobieta to fikcja - oznaczająca różnicę, niedefiniowalna, niemożliwa do określenia tożsamość. W tym przypadku męskość i kobiecość to po prostu strój/styl/maska, jeszcze jedna kategoria językowa ${ }^{65}$.

Feministki różnicy, krytykując esencjalizm, odrzucają - za dekonstrukcjonistami - „wszelkie słowniki, które »pasożytują na myśli fallogocentrycznej«, nieuchronnie zwracającej się ku jedności czy totalności, co uniemożliwia dotarcie do partykularnej różnicy" ${ }^{\text {"66 }}$. Innymi słowy, feministki postmodernistyczne zajmują się poszukiwaniem przyczyn represji tego, co kobiece w porządku symbolicznym (w języku). Uciekają jednocześnie od wszelkich określeń kobiecości, eksploatując zmienność, różnorodność i rozproszenie kobiet (np. według Kristevej kobieta to „brak”; Irigaray mówi o „wielości kobiet”, zaś Butler stwierdza, że „kobieta jako taka nie istnieje" ${ }^{" 67}$ ).

62 D. Riley, Am I That Name? Feminism and the Category of »Women « in History;

cyt. za: J. Mizielińska, »Sen, co kusi...« ..., op. cit., s. 38.

63 J. Mizielińska, »Sen, co kusi... ..., op. cit., s. 35.

64 J. Bator, Feminizm i postmodernizm - powinowactwo z wyboru?, op. cit., s. 87.

65 Ibidem, s. 85-87.

66 M. Środa, Indywidualizm i jego krytycy ..., op. cit., s. 250.

67 J. Mizielińska, »Sen, co kusi...» ..., op. cit., s. 35. 
Pluralizacja różnic(y) otwiera wprawdzie nowe możliwości poszukiwania „kobiecej/ych wersji historii”, a tym samym pozwala na przełamanie monopolu dyskursu modernistycznego. Jednak dyskursywizacja kategorii podmiotu, wiążąca się z praktyką dekonstrukcyjną, oznacza ,fikcję kobiety" i niemożność zrealizowania projektu kobiecej emancypacji. Zwraca na to uwagę Seyla Benhabib, która pisze o groźbie rozpłynięcia się feministycznej narracji w powodzi innych dyskursów:

„Należy stworzyć pewien wspólny grunt lub pewną przestrzeń między tym, co prywatne, i tym, co publiczne, by feminizm nie został pozbawiony tego, co jest w nim tak cenne, mianowicie projektu emancypacji; by zainteresowanie i praca włożone w propagowanie kwestii różnorodności, różnicy i Inności przez współczesną filozofię feministyczną nie spowodowały zniknięcia »problemu kobiecego«, a więc i procesów indywidualizacji w ich funkcjach emancypacyjnych" ${ }^{\text {"68 }}$.

Niewątpliwie poststrukturalistki, skupiając się tak silnie na różnicy, umacniają nowe myślenie o kulturze w kategoriach odmienności i zmienności. „Śmierć Oświecenia”, ogłoszona przez postmodernistów, oznacza kres jednej historii i jednej interpretacji (męskiej). Otwiera za to możliwość opowiadania o zdarzeniach z pozycji „Innego”.

Odrzucając definicje kobiecości i męskości, feministki różnicy wyrażają pragnienie uwzględnienia w dyskursie dominującym głosów mniejszości, chcą mówić z pozycji inności. Jednak całkowita negacja wspólnego doświadczenia kobiet (esencji kobiecości) grozi jednak pluralizacją różnic i „rozpłynięciem się” kobiecego głosu (,własnego głosu”) w powodzi innych dyskursów. Dlatego tak ważne staje się dla feminizmu (szczególnie w jego „odłamie” esencjalistycznym) ustalenie, że „istnieje jakiś substrat [...], który rozstrzyga o istocie ludzi w ich jednostkowości i odrębności i który zarazem stanowić może podstawę reprezentatywnego podmiotu zbiorowego, będącego nośnikiem określonych ról lub - patrząc inaczej - przedmiotem opresji lub emancypacji" ${ }^{\prime 69}$. Mówiąc wprost: istnieje esencja kobiecości i męskości, która opiera się na wspólnym doświadczeniu kobiet jako opresjonowanych i mężczyzn jako opresorów.

U podstaw wspólnego doświadczenia kobiet leży, zdaniem esencjalistek (nazywanych w innym ujęciu kulturalistkami), wielowiekowe przy-

68 S. Benhabib, Situating the Self. Gender, Community and Postmodernism in Contemporary Ethics, New York 1992; cyt. za: M. Środa, Indywidualizm i jego krytycy ..., op. cit., s. 253-254.

${ }^{69}$ M. Środa, Indywidualizm i jego krytycy ..., op. cit., s. 248. 
pisywanie ich do sfery prywatnej: natury, fizjologii, ciała, reprodukcji itp. Feministki kulturalne wierza, że wykluczenie ze sfery władzy i wpływów, które zawsze było przekleństwem kobiet, dziś może, paradoksalnie, stać się źródłem ich siły. Adrienne Rich i Mary Daly upatrują źródeł tej siły w macierzyństwie ${ }^{70}$. Nel Noddings i Carol Gilligan mówią o kobiecym „myśleniu sercem”, ,etyce troski” opartej na emocjach, miłości do bliźnich, empatii itp. ${ }^{71}$ Ekofeministki wskazują na nowy wariant etyki ekologicznej, u podstaw której leży szczególna bliskość kobiet i natury. W tym, co było dotąd przyczyną opresji, upatrują dziś szans na wyzwolenie ${ }^{72}$.

Doświadczenie kobiecego ciała znalazło się również w centrum poszukiwań feministycznej krytyki literackiej spod znaku écriture féminine, inspirowanej teorią Lacana. Zdaniem teoretyczek écriture féminine istnieje głęboki związek ciała/seksualności i tekstu. Pisanie nie jest warunkiem ujawnienia różnicy seksualnej, jest tylko sposobem pokazania kobiecości: „Według Lacana tożsamość strukturuje się w języku - seksualność jest więc tekstualna. Zapisana w tekstach kultury i przez nie nauczona"73. W „słabej” wersji tej teorii jest miejsce na odkrycie języka kobiet - języka preedypalnego, pierwszego, który wiąże się raczej z figurą Matki niż Ojca: „W fazie preedypalnej słowo odzyskuje związek z ciałem mówiącego, z rytmem jego narządów głosu" - pisze Julia Kristeva ${ }^{74}$. W innym miejscu zwraca jednak uwagę, że ,język kobiet to język umarły”: „Język kobiecy przetrwał jedynie w micie, w opowieściach o tajemnym środku komunikacji w państwie Amazonek, w bajkach przenoszących nas w czasy matriarchatu", 75 .

70 Por. np. A. Rich, Zrodzone z kobiety. Macirzyństwo jako doświadczenie i instytucja, przeł. J. Mizielińska, Warszawa 2000; M. Daly, Gyn/Ecology: The Metaethics of Radical Feminism, Boston 1978.

71 Por. N. Noddings, Carring: A Feminine Approach to Ethics and Moral Education, Berkeley 1984.

${ }^{72} \mathrm{O}$ ekofeminizmie i innych odłamach feminizmu pisze R. Putnam Tong, Myśl feministyczna ..., op. cit.

73 A. Araszkiewicz, Dotknięcie ciała. Literacka strategia Anieli Gruszeckiej, w: Krytyka feministyczna: siostra teorii i historii literatury, pod red. G. Borkowskiej, L. Sikorskiej, Warszawa 2000, s. 123.

${ }^{74}$ G. Borkowska, Metafora drożdży. Co to jest literatura/poezja kobieca, w: Ciało i tekst. Feminizm w literaturoznawstwie-antologia przekładów, pod red. A. Nasiłowskiej, Warszawa 2001, s. 70.

G. Borkowska, Córki Miltona (o krytyce feministycznej ostatnich piętnastu lat), w: Po strukturalizmie. Wspótczesne badania teoretycznoliterackie, pod red. R. Nycza, Wrocław 1992, s. 78. 


\section{Wnioski}

Poszukiwania wspólnoty kobiecego doświadczenia napotykają na wiele trudności. Są wśród nich przeszkody polityczne i społeczne (różnice rasowe, klasowe, religijne, orientacji seksualnej itp.); nie ma zgody co do tożsamości podmiotu-kobiety; zawodzą próby ustalenia kobiecej odrębności językowej. Przeciwnicy feminizmu, którzy mówią o „waginocentryzmie” i „feminokracji”, mogą odetchnąć z ulgą: „Monologi waginy” wciąż słychać wyłącznie w teatrze ${ }^{76}$. Wprawdzie feministki (czy szerzej: kobiety) mają prawo do własnej opowieści: mogą być „opowiadaczem” nowej wersji mitu, pod warunkiem jednak, że istnieje przestrzeń dla tej opowieści. A w przestrzeni publicznej (w narracji mediów) feministki nadal są antagonista, „Innym”. Głos, który nie jest słyszalny w mediach głównego nurtu, jest jak krzyk rozbrzmiewający w dźwiękoszczelnym pomieszczeniu. Jeśli feministki nie opowiedzą swojej historii w masowych środkach przekazu (tylko na przykład we własnych, niszowych, mediach), grozi im zamknięcie w getcie tzw. dyskursów mniejszości, do którego prowadzi wyłącznie furtka „politycznej poprawności”. Coraz częściej słychać zatem wątpliwości, czy taki sposób egzystowania feminizmu w mediach nie stanie się przypadkiem nową formą wykluczenia - inną formą Inności?

\section{Summary}

Since the very beginning, feminism has been surrounded by numerous legends, myths and not-quite-credible stories that generally stem from the miscomprehension of its ideas. It still continues to be presented in a caricatured and stereotypical manner. The media have a considerable share in creating such attitudes to feminism, as they construct the majority of their accounts of the feminist movement around the ,interrelated activities of an antagonist and protagonist". The search for the common nature of feminine experience faces numerous obstacles. These involve political and social ones (differences of race, class, religion, sexual orientation, etc.); the identity of the subject-woman has not been agreed; the attempts to establish feminine language fail. It is increasingly questioned whether this manner of presenting feminism in the media is not becoming a new form of exclusion - a new form of Differentness.

76 E. Ensler, Monologi waginy, przeł. A. Kołyszko, Warszawa 2003. 